\title{
PEMANFAATAN PERANGKAT TIK BANTUAN USO UNTUK PEMBELAJARAN DI SMPN 2 SAKRA, KABUPATEN LOMBOK TIMUR
}

\author{
Utilization of USO-ICT Equipment for Learning in SMPN2 Sakra, \\ Lombok Timur District
}

Supandri dan Sudirman Siahaan

Pemerhati bidang Teknologi Pembelajaran

andi.btkpdikpora@gmail.com dan pakdirman@yahoo.com

\begin{abstract}
ABSTRAK: Universal Service Obligation (USO) merupakan program gratis penyedia jasa berbasis WiFi dari pemerintah pusat sebagai ruang pelayanan publik untuk teknologi internet (interconnection networking). Program ini merupakan program kerja sama antara Kementerian Komunikasi dan Informatika (Kemkominfo) dengan Kementerian Pendidikan dan Kebudayaan (Kemendikbud). Tujuannya adalah memfasilitasi sekolah-sekolah di daerah terdepan, terpencil, dan tertinggal (3T) agar dapat memanfaatkan perangkat Teknologi Informasi dan Komunikasi (TIK) dan sarana pendukungnya untuk kepentingan pembelajaran dan komunikasi. Guru dan peserta didik diharapkan dapat memanfaatkannya seoptimal mungkin untuk mengakses konten pembelajaran melalui berbagai sumber sehingga kegiatan pembelajaran menjadi menarik dan sekaligus menantang. Tulisan ini merupakan studi kasus yang dilaksanakan di SMPN 2 Sakra, Kabupaten Lombok Timur, Provinsi Nusa Tenggara Barat. Fokus penelitian ini adalah mengenai sejauh mana pemanfaatan fasilitas TIK bantuan USO untuk pembelajaran,baik yang berkaitan dengan pelaksanaan, dampak, tantangan, dan peluang pengembangannya.Tujuannya adalah untuk mengetahui sejauh mana perangat TIK bantuan USO sudah dimanfaatkan untuk pembelajaran. Metoda yang digunakan untuk mendapatkan data dan informasi adalah wawancara, observasi (pengamatan), dan dokumentasi. Data dan informasi yang telah dikumpulkan, dikelompokkan untuk dianalisis dan disajikan secara deskriptif. Hasil penelitian mengungkapkan bahwa belum semua guru dan peserta didik memanfaatkan perangkat TIK bantuan USO yang tersedia di sekolah untuk pembelajaran.
\end{abstract}

Kata Kunci: Teknologi Informasi dan Komunikasi (TIK), pembelajaran, USO.

ABSTRACT: Universal Service Obligation (USO) is a Free Wifi Service Program from the central government for the public (interconnection networking). This is a collaborative program between the Ministry of Communication and Informatics and the Ministry of Education and Culture. The objective of the program is to facilitate schools in the frontier, remote, and left areas in utilizing ICT and supporting infrastructures for the 
necessity of learning and communication purposes. It is hoped that teachers and students can optimally utilize it in accessing the learning contents so that the learning activities become interesting as well as triggering. This article is a case study conducted in SMPN 2 Sakra, Lombok Timur District, Nusa Tenggara Barat Province. The focus of this study is the utilization of USO-ICT equipment for learning, related to the conduct, impact, challenges, and its development possibility. The objective of this study is to know how far the USO-ICT equipment and its facility has been utilized for learning. The data and information is collected through interview, observation, and documentation. Then, the gathered data and information is grouped to be analyzed and presented descriptively. The result shows that not all teachers and students have already utilized the available USO-ICT equipment for learning.

Keywords: Information and Communication Technology (ICT), learning, USO.

\section{PENDAHULUAN}

Pada umumnya, masalah-masalah yang dihadapi sekolah-sekolah di daerah Terdepan, Terpencil, dan Tertinggal (3T) antara lain adalah yang berkaitan dengan ketersediaan: (1) sumber daya tenaga listrik (UNESCO, 2013); (2) sumber-sumber belajar digital; (3) sumber daya manusia yang memiliki pengetahuan dan kemampuan di bidang pemanfaatan teknologi informasi dan komunikasi (TIK) (Pustekkom, 2012); dan (4) ketersediaan perangkat TIK yang terbatas yang dimiliki sekolah untuk kepentingan pembelajaran.

Kondisi keterbatasan perangkat dan fasilitas serta kemampuan guru di bidang pemanfaatan peralatan TIK tidak mengurangi semangat dan motivasi guru di daerah 3T untuk belajar memanfaatkan TIK untuk pembelajaran. Bahkan mereka ini sangat antusias dan ingin cepat dapat memanfaatkan perangkat dan fasilitas TIK untuk membelajarkan peserta didiknya. Guru merasa sangat senang dan terbantu dengan adanya perangkat dan fasilitas TIK (Rivalina, 2015) karena menurut Sudirman Siahaan (Siahaan, 2015) yang merujuk pendapat Rahmi Rivalina dan Sudirman Siahaan, pemanfaatan TIK di dalam kegiatan pembelajaran membuat suasana atau kondisi pembelajaran menjadi lebih menarik, menyenangkan, efisien, dan bervariasi. Peserta didik menjadi lebih termotivasi untuk belajar di sekolah setiap hari karena mereka senang dengan model pembelajaran yang memanfaatkan TIK yang dilakukan guru (Rivalina dan Siahaan, 2013).

Sekolah-sekolah yang berada di daerahdaerah yang termasuk kategori 3T akan sulit bangkit jika semata-mata hanya mengandalkan potensi, baik yang dimilikinya maupun potensi yang ada di lingkungan sekitarnya. Diperlukan semacam "campur tangan" dari pihak luar (baik instansi pemerintah maupun non pemerintah) yang memberikan terobosan (breakthrough) sehingga sekolah-sekolah di daerah $3 \mathrm{~T}$ ini dapat bangkit dan sama-sama bergerak maju sebagaimana sekolah-sekolah lain pada umumnya.

Di daerah-daerah perdesaan tertentu, memang ada berbagai inisiatif atau upaya yang dilakukan masyarakat setempat sehingga di kelompok masyarakat tersebut tersedia sumber tenaga listrik sekalipun hanya berfungsi pada malam hari. Demikian juga dengan beberapa sekolah tertentu, ada beberapa pimpinan sekolah yang dengan berbagai upaya atau inisiatifnya telah dapat melengkapi sekolah yang dipimpinnya dengan sumber tenaga listrik sekalipun kapasitasnya masih sangat terbatas sesuai dengan kemampuan sekolah. 
Kebijakan pemerintah di bidang penyediaan sumber tenaga listrik yang dikenal dengan "listrik masuk desa" sangat dirasakan manfaatnya oleh masyarakat. Sekalipun memang di berbagai daerah tertentu, sumber tenaga listrik hanya berfungsi atau hidup pada malam hari tetapi masyarakat sangat mensyukuri dan menikmatinya. Diharapkan secara bertahap, ketersediaan sumber tenaga listrik selama 24 jam akan dapat menjangkau seluruh daerah perdesaan. Ketersediaan sumber tenaga listrik tentunya tidak hanya akan berfungsi sebagai alat penerangan saja tetapi lebih jauh lagi akan berpengaruh pada berbagai bidang lainnya dalam kehidupan sehari-hari, termasuk juga bidang pendidikan.

Dengan tersedianya sumber tenaga listrik di sekolah, terbukalah peluang bagi sekolah yang bersangkutan untuk memanfaatkan kemajuan TIK bagi kepentingan pembelajaran. Secara khusus dan bertahap, setelah sekolah-sekolah di daerah 3T memiliki sumber tenaga listrik yang berfungsi selama 24 jam, akan ada program atau kebijakan ikutan yang diharapkan dapat dimanfaatkan sekolah dalam membelajarkan para peserta didik dan masyarakat sekitarnya. Dalam kaitan ini, salah satu bentuk kebijakan atau program "campur tangan" yang dilakukan pemerintah adalah yang dikenal dengan program Universal Service Obligation (USO).

Terkait dengan program bantuan USO ini, Rini Cahyani dan Iwan Krisnadi mengemukakan bahwa USO merupakan bagian dari kewajiban pemerintah dalam memberikan pelayanan universal di bidang telekomunikasi dan informatika kepada publik. Kewajiban pelayanan tersebut, menurut Rini Cahyani dan Iwan Krisnadi, dilakukan untuk mengurangi kesenjangan digital di daerah khususnya daerah perdesaan, terpencil, dan tertinggal yang secara ekonomi sulit dilakukan oleh penyelenggara telekomunikasi komersial (http://www.academia.edu/37960956/ Studi_Komparasi_Penerapan_Universal_Service_ Obligation_Bidang_Telekomunikasi). Program bantuan USO di bidang pemanfaatan TIK untuk bidang pendidikan ini digagas dan dilaksanakan oleh Kementerian Komunikasi dan Informatika (Kemkominfo) bekerjasama dengan Kementerian Pendidikan dan Kebudayaan (Kemendikbud) (Suharwoto, 2018).

Beberapa perangkat bantuan yang diberikan ke sekolah-sekolah adalah perangkat Pembangkit Listrik Tenaga Surya (PLTS) bagi sekolah-sekolah yang belum memiliki sumber tenaga listrik, perangkat VSAT (Very Small Apperture Terminal) untuk mengatasi sulit atau tidak adanya signal telekomunikasi (blank spot), antena parabola dan pesawat televisi untuk menangkap siaran Televisi Edukasi (TVE), sebuah laptop yang berfungsi sebagai server sekolah yang berisi berbagai jenis konten pembelajaran, 5 unit komputer/laptop (clients), sebuah proyektor LCD (liquid crystal display), dan modem untuk akses internet (Warsihna, 2013; Siahaan, 2013).

Melalui bantuan perangkat dan konten pembelajaran digital yang diberikan ke sekolah-sekolah, diharapkan sekolah-sekolah tersebut menjadi terfasilitasi untuk memanfaatkan koneksi internet bagi kepentingan pembelajaran dan komunikasi (Humas BP3TI Kominfo, 2016). Dengan bantuan layanan koneksi internet, baik guru maupun peserta didik menjadi terfasilitasi untuk mengakses berbagai sumber belajar yang tersedia di dunia maya guna memperkaya khasanah pengetahuan mereka seoptimal mungkin.

Diana Ariani mengidentifikasi potensi teknologi informasi dan komunikasi yang antara lain adalah untuk: (1) peningkatan akses memperoleh informasi dari mana saja, oleh siapa saja, kapan saja, dan tentang apa saja; (2) peningkatan efektivitas komunikasi dengan berbagai bentuk rangsangan indera; (3) peningkatan relevansi dengan kebutuhan yang semakin banyak dan beragam; (4) penyesuaian dengan kondisi lingkungan yang berubah; dan (5) peningkatan efisiensi dengan menghemat waktu, tenaga, dan biaya (Ariani, 2009).

Latar belakang program USO Telekomunikasi dan Informatika, menurut Humas BP3TI KOMINFO (2016) adalah sebagai "Konsep Kewajiban Pelayanan Universal (KKPU) atau Universal Service Obligation (USO) Telekomunikasi dan Informatika dan jawaban untuk 
mengupayakan pemerataan jaringan TIK di tanah air" (https://humasbp3tikominfo.word press.com/2016/07/16/latar-belakangprogram -uso-telekomunikasi-dan-informatika/).

Sasaran pengguna program bantuan USO adalah sekolah-sekolah yang berlokasi di daerah 3T dengan asumsi bahwa sebagian besar peserta didik yang bersekolah adalah berdomisili atau bertempat tinggal di desa pinggiran. Pertimbangan lainnya adalah bahwa pembangunan jaringan (networking) dalam layanan infrastruktur TIK di sekolahsekolah belum merata. Dalam kaitannya dengan program bantuan USO ini, Eko Marwanto mengungkapkan bahwa program ini merupakan jaminan ketersediaan pelayanan publik bagi setiap warga negara, khususnya pelayanan telekomunikasi dan informatika (https://www.ekomarwanto.com/ 2012/07/informasi-program-uso-universalservice.html). Lebih jauh dikemukakan bahwa program bantuan USO yang berupa penyediaan perangkat dan jaringan internet merupakan salah satu upaya pemerintah dalam melakukan pembangunan di bidang telematika yang berbasiskan teknologi digital yang tersebar di seluruh wilayah tanah air.

Program bantuan USO ini dinilai penting karena kemajuan TIK yang sangat pesat akan memudahkan masyarakat secara bebas mengakses berbagai jenis informasi tanpa mengenal batasan negara dan waktu. Inovasi teknologi terutama teknologi informasi dan komunikasi juga sangat memengaruhi berbagai sektor kehidupan, seperti sektor pemerintahan, perekonomian, sosial budaya, serta sektor pertahanan dan keamanan suatu negara. Konsep Kewajiban Pelayanan Universal ini muncul sebagai jawaban untuk mengupayakan pemerataan jaringan internet dalam membangun layanan publik di semua sektor pembangunan pada umumnya, dan secara khusus di bidang pembangunan pendidikan (Humas BP3TI Kominfo, 2016).

Selama dua tahun, program bantuan USO ini berhasil menjembatani akses internet di 605 sekolah di kawasan daerah 3T yang belum mendapatkan sentuhan teknologi karena minimnya akses. Sekolah yang berada di kawasan pedalaman umumnya sulit mendapatkan infrastruktur pendidikan (https:/ /kominfo.go.id/content/detail/8444/programuso-mampu-jembatani-akses-internet-605sekolah/0/sorotan_media) (Diakses tgl 23/01/ 19).

Pemanfaatan TIK dalam dunia pendidikan (termasuk akses koneksi internet) dapat mempermudah pembelajaran, menciptakan kegiatan pembelajaran yang menyenangkan, mendorong peningkatan prestasi belajar peserta didik, dan yang pada akhirnya bermuara pada peningkatan mutu pembelajaran (Santoso, 2016). Pendapat Santoso ini didukung oleh hasil penelitian Hariadi (2016) yang menyimpulkan antara lain bahwa pemanfaatan TIK dalam pelajaran ekonomi menjadikan pembelajaran lebih menarik, membantu siswa menyelesaikan tugas, dan meningkatkan pemahaman siswa dalam belajar. Selain itu, hasil belajar siswa menjadi lebih tinggi dibandingkan dengan hasil belajar siswa saat menggunakan media konvensional.

Hasil penelitian lain yang relevan adalah yang dilakukan oleh Muchamad Taufiq Anwar (2016). Hasil penelitiannya menyimpulkan bahwa siswa SMA negeri dan swasta di kota Salatiga memberikan persepsi positif terhadap penggunaan TIK dalam pembelajaran karena TIK dianggap memberi kemudahan dalam mencari sumber belajar.

Tujuan utama program bantuan USO ini adalah untuk mengatasi/menjembatani kesenjangan digital (digital gap) atau melaksanakan pemerataan jaringan teknologi informasi dan komunikasi antarsekolah di seluruh penjuru tanah air. Secara khusus untuk mengisi ruang kosong teknologi dan media pembelajaran di sekolah (Aziz, dkk., 2016).

Sesuai dengan tujuannya, target atau cakupan sasaran program KKPU adalah wilayah pelayanan universal yang meliputi daerah-daerah terpencil, perbatasan, perintisan, dan daerah yang belum mendapatkan akses atau jaringan telekomunikasi. Program-program KKPU meliputi: (1) Desa Dering (penyediaan telekomunikasi telepon); (2) Desa Pintar,Pusat Layanan Internet Kecamatan (PLIK); dan (3) Mobile Pusat Layanan Internet Kecamatan (sama dengan PLIK namun berkeliling desa dengan mobil) (Humas BP3TI 
Kominfo, 2016).

Pada tahun 2013, program KKPU berkembang menjadi: Nusantara Internet Exchange, PLIK Sentra Produktif, Jalin KPU/ USO (Jasa Akses Layanan Internet berupa WIFI Kabupaten), dan Telinfo Tuntas (Telekomunikasi dan Informatika di Pulau Terluar dan Perbatasan) (https://id.wikipedia. org/wiki/Kewajiban_Pelayanan_Universal).

Selanjutnya, Peraturan Menteri Komunikasi dan Informatika Nomor 25 Tahun 2015 tentang Pelaksanaan Kewajiban Pelayanan Universal Telekomunikasi dan Informatika menyatakan bahwa KKPU memiliki karakteristik yaitu pembangunan dilaksanakan secara komprehensif dengan mengintegrasikan pembangunan infrastruktur TIK dengan pengembangan ekosistem TIK seperti SDM, aplikasi, dan konten yang mendukung (https://jdih.kominfo.go.id/ produk_hukum/view/id/357/t/peraturan+ menteri+komunikasi+dan+informatika+nomor+ 25+tahun+2015+tanggal+1+juli+2015).

Di bidang pengembangan SDM, Kementerian Pendidikan dan Kebudayaan bekerjasama dengan Kementerian Komunikasi dan Informatika menyediakan ruang pelayanan publik untuk teknologi internet (interconnection networking) berbasis WIFI. Melalui kerjasama kedua lembaga Kementerian ini, seperangkat peralatan canggih diberikan dalam jumlah yang terbatas ke sekolah-sekolah yang berada di wilayah 3T. Beberapa di antaranya adalah berbagai jenis gawai atau peralatan yang dapat digunakan untuk kepentingan pendidikan/ pembelajaran dan melakukan komunikasi. Diharapkan sekolah-sekolah penerima program bantuan USO akan dapat memanfaatkannya secara optimal bagi kepentingan pelayanan pembelajaran berbasis TIK.

Pemilihan dan penetapan sekolah-sekolah yang berada di wilayah 3T sebagai penerima bantuan perangkat VSAT dilakukan secara bertahap mulai tahun 2015. Bantuan perangkat VSAT ini akan memfasilitasi sekolah terkoneksi dengan jaringan internet. Tujuan pemberian bantuan VSAT ini adalah untuk menyambut perkembangan teknologi pembelajaran yang mengalami perubahan kearah industri 4.0 di mana perangkat sudah berbasis digital. Artinya, segala bentuk teknologi informasi sudah ada di ujung jari yang terkoneksi dalam suatu sistem hardware dan software.

Pada awalnya, upaya untuk memberdayakan sekolah-sekolah di daerah 3T di bidang pemanfaatan TIK dalam kegiatan pembelajaran, baik yang berupa siaran televisi maupun internet sudah mulai dirintis oleh Pusat Teknologi Informasi dan Komunikasi Pendidikan dan Kebudayaan, Kementerian Pendidikan dan Kebudayaan (Pustekkom, Kemendikbud) pada tahun 2011. Sesuai dengan kemampuan yang dimiliki, perintisan pemanfaatan TIK untuk kepentingan pembelajaran di sekolah-sekolah di daerah 3T hanya dapat dilakukan secara terbatas, yaitu di 5 provinsi yang mencakup 10 sekolah (5 SD atau yang sederajat dan 5 SMP atau yang sederajat) (Pustekkom, 2011).

Agar sekolah-sekolah, baik di daerah perkotaan maupun di daerah $3 T$ dapat memanfaatkan TIK untuk pembelajaran, yang pertama-tama dan utama dilakukan adalah mempersiapkan tenaga pendidik dan kependidikan yang akan berperanserta agar memiliki kompetensi di bidang TIK. Pemikiran yang demikian ini didukung oleh hasil penelitian yang dilakukan Chaidar Husain (2014). Salah satu kesimpulan hasil penelitiannya adalah bahwa guru yang belum memiliki kompetensi di bidang TIK akan tetap membelajarkan peserta didiknya melalui penerapan metode pembelajaran yang tradisional. Oleh karena itu, para guru ini perlu mendapatkan pelatihan dan bimbingan agar memiliki kompetensi di bidang TIK (baik pengetahuan dan keterampilan di bidang pengembangan konten maupun pemanfaatan TIK untuk kepentingan pembelajaran).

Langkah berikutnya setelah mendapatkan pelatihan dan bimbingan adalah melakukan simulasi pemanfataan perangkat dan fasilitas yang diberikan untuk penyelenggaraan kegiatan pembelajaran berbantuan TIK. Kegiatan simulasi ini (mulai dari pemberian apersepsi sampai dengan pemberian tugas atau evaluasi hasil belajar) disupervisi langsung oleh narasumber dari Pustekkom, Kemendikbud. Kemudian, hasil simulasi 
didiskusikan bersama antara narasumber dengan para guru untuk penyempurnaan kegiatan pembelajaran yang berikutnya.

Selanjutnya, pada tahun 2015, upaya pemberdayaan sekolah-sekolah di daerah $3 \mathrm{~T}$ lainnya dilanjutkan secara bertahap dari tahun ke tahun sehingga jumlahnya terus meningkat. Perkembangan selanjutnya yang dapat dicatat adalah bahwa pelayanan berbagai konten pembelajaran berbasis elektronik sudah disediakan pemerintah melalui situs-situs edukasi. Layanan pemerintah berbasis elektronik ini merupakan suatu visi untuk mengembangkan penyelenggaraan kepemerintahan yang berbasis elektronik menuju Indonesia bermutu dalam memanfaatkan TIK. Pemerintah sendiri secara terpadu telah membangun dan melakukan penataan berbagai layanan perangkat telematika bagi masyarakat dengan cara mengoptimalkan pemanfaatan TIK yang aman, sehat, dan modern dengan kualitas baik serta harga terjangkau.

Pada prinsipnya, permasalahan yang dihadapi sekarang ini adalah terbatasnya gawai yang digunakan dalam proses belajarmengajar di kelas. Sejatinya,setiap ruang kelas dilengkapi dengan jaringan internet dan daya listrik yang cukup, jaringan LAN, dan proyektor LCD. Namun pada kenyataannya, kondisi yang demikian ini belum terpenuhi. Mengingat masih belum semua guru memiliki laptop, masih banyak guru yang memilih menggunakan bahan belajar modul dan bahan belajar lainnya sebagaimana pada lazimnya yang dimiliki masing-masing guru bidang studi.

Memang harus diakui bahwa bantuan perangkat dan fasilitas yang diberikan ke sekolah-sekolah melalui program bantuan USO masih terbatas. Namun pertanyaan atau yang menjadi masalah adalah sudah sejauh manakah sekolah-sekolah penerima bantuan memanfaatkan perangkat dan fasilitas yang terbatas tersebut secara terintegrasi di dalam kegiatan pembelajaran. Masalah inilah yang menjadi fokus bahasan di dalam artikel ini. Adapun yang menjadi tujuan penelitian adalah untuk mendeskripsikan pelaksanaan pemanfaatan perangkat TIK bantuan program USO di SMPN 2 Sakra, Kabupaten Lombok Timur, baik keberhasilan, kendala/tantangan, maupun peluang pengembangan lebih lanjut.

\section{METODA}

Di Nusa Tenggara Barat, khususnya di Kabupaten Lombok Timur, sekolah-sekolah penerima perangkat dan fasilitas program bantuan USO adalah: (1) SMKN 1 Sambalia; (2) SMPN 2 Sakra; (3) SMPN5 Sikur; dan (4) SMAN Masbagik (Pustekkom, 2018). Mengingat berbagai keterbatasan yang ada, penelitian ini hanya dilaksanakan di SMPN 2 Sakra, Lombok Timur sebagai salah satu sekolah penerima program bantuan USO. Dengan demikian, penelitian ini merupakan sebuah studi kasus. Penelitian kasus ini dilaksanakan pada rentang waktu mulai dari Oktober sampai dengan Desember 2018 sesuai dengan ketersediaan waktu bersama antara pihak sekolah dengan penulis yang melakukan penelitian.

Pengumpulan data dan informasi dilakukan dengan menggunakan teknik sebagai berikut.

1. Wawancara, tidak hanya ditujukan kepada para guru yang telah membelajarkan peserta didiknya melalui pemanfaatan perangkat TIK program bantuan USO yang tersedia di sekolah; tetapi juga ditujukan kepada peserta didik yang mengikuti kegiatan pembelajaran melalui pemanfaatan TIK (peserta didik dipilih secara acak) guna mendapatkan informasi mengenai pemanfaatan layanan internet yang tersedia untuk menunjang kegiatan pembelajaran mereka.

2. Observasi atau pengamatan terhadap kegiatan pembelajaran yang dilaksanakan guru. Selama observasi, peneliti mengamati sejauh mana para guru telah memanfaatkan perangkat TIK yang ada untuk membelajarkan peserta didiknya, baik kendala yang dihadapi maupun faktor pendukung keberhasilan pelaksanaan kegiatan pembelajaran.

3. Dokumentasi yang dilakukan dengan mempelajari berbagai dokumen yang tersedia yang terkait dengan pelaksanaan tindak lanjut program bantuan USO.

Kemudian, data dan informasi yang diperoleh melalui ketiga teknik pengumpulan 
tersebut di atas, dikelompokkan sesuai dengan aspek keterlaksanaan, kemanfaatan, kendala, dan pendukung terhadap pemanfaatan TIK dalam kegiatan pembelajaran. Kemudian, data yang telah dikelompokkan tersebut dibersihkan dan dianalisis kecenderungan dominannya. Terkait dengan aspek kebijakan, dilakukan klarifikasi dan konfirmasi terhadap perkembangan terakhirnya, baik dengan Kepala Sekolah maupun dengan tenaga kependidikan lainnya. Hasil analisis disajikan secara deskriptif.

\section{HASIL DAN PEMBAHASAN}

Dalam pengelolaan perangkat dan fasilitas program bantuan USO di sekolah-sekolah khususnya yang termasuk ke dalam kategori daerah 3T, ada 4 (empat) komponen dasar yang perlu diperhatikan, yaitu: (1) technoware; (2) humanware; (3) infoware; dan (4) orgaware. Keempat komponen dasar tersebut merupakan suatu rangkaian yang tidak terpisahkan antara yang satu dengan yang lainnya. Istilah lain yang digunakan Pustekkom untuk keempat komponen yang harus dipenuhi agar dapat mendayagunakan TIK untuk pendidikan secara baik adalah: (1) infrastruktur (hardware, software, dan akses); (2) materi pembelajaran digital; (3) sumber daya manusia (SDM); dan (4) kebijakan. Di daerah 3T, umumnya bukan hanya infrastruktur yang tidak tersedia, tetapi SDM juga yang belum siap, konten digital yang belum tersedia ditambah lagi dengan perangkat kebijakan yang belum mendukung (Pustekkom, 2012a). Technoware yang dalam hal ini merupakan bantuan perangkat USO yang diberikan ke sekolah-sekolah. Ada peralatan tambahan yang diterima sekolah dari provider ICON Plus yaitu yang berupa alat, seperti: telways, routerboard/mixrotik, wifi portable, dan Box FO (SMPN-2 Sakra, 2018).

Semua gawai atau peralatan yang diberikan ke sekolah merupakan kumpulan berbagai hardware dan software yang dirangkai dalam suatu aplikasi tertentu sehingga dapat digunakan untuk media komunikasi dalam proses pembelajaran di sekolah. Gawai atau peralatan tersebut berfungsi sebagai mesin pencari (search engine), pengolah data, fasilitas chatting, email, frensetter, facebook, WhatsApp (WA), kuis online, dan video conference. Mengingat bahwa perangkat bantuan USO itu dirancang untuk terkoneksi dengan internet, para guru diharapkan dapat melaksanakan aktivitas $e$ learning dengan konsep pendidikan yang memanfaatkan TIK dalam proses pembelajaran.

Berdasarkan hasil wawancara dengan Kepala SMPN 2 Sakra, diperoleh informasi bahwa Kepala Sekolah telah menetapkan kebijakan penggunaan dana Biaya Operasional Sekolah (BOS) untuk membangun Ruang Komputer dengan tujuan agar dapat melaksanakan kegiatan pembelajaran dengan memanfaatkan TIK. Mengingat sebagian guru yang mengajar di sekolah ini telah memiliki laptop pribadi, Kepala Sekolah merasa sangat optimis tentang keterlaksanaan pendayagunaan TIK dalam kegiatan pembelajaran kedepan. Upaya lain yang dilakukan Kepala sekolah adalah mendatangkan narasumber dari sekolah lain untuk melatih para guru SMPN 2 Sakra tentang bagaimana cara membuat media pembelajaran sesuai kebutuhan.

Di samping untuk kepentingan kegiatan belajar mengajar, ketersediaan perangkat TIK juga dirancang untuk kepentingan pelaksanaan Ujian Nasional Berbasis Komputer (UNBK). Dalam kaitan ini, Kepala Sekolah juga telah menyiapkan 2 ruangan untuk laboratorium komputer yang telah dilengkapi dengan jaringan LAN serta WLAN yang terhubung dengan dua unit server. Dengan demikian, diharapkan SMPN 2 Sakra kedepannya akan semakin mantap dalam mengembangkan kegiatan pembelajaran berbasis TIK.

Berdasarkan sumber data dari Kepala SMPN 2 Sakra, pada awalnya, hanya 7 dari 48 guru $(14,58 \%)$ yang tidak hanya tergugah tetapi bahkan lebih jauh lagi telah melaksanakan kegiatan pembelajaran menggunakan TIK di ruang laboratorium komputer.

Sebagian besar guru lainnya cenderung masih menggunakan buku paket atau media lainnya. Beberapa faktor yang menyebabkan sebagian besar guru belum memanfaatkan 
perangkat TIK bantuan USO disajikan pada Tabel 1 berikut ini. Salah satu faktor penyebab sebagian besar guru belum memanfaatkan TIK dalam pembelajaran adalah dikarenakan belum memiliki perangkat laptop sendiri.

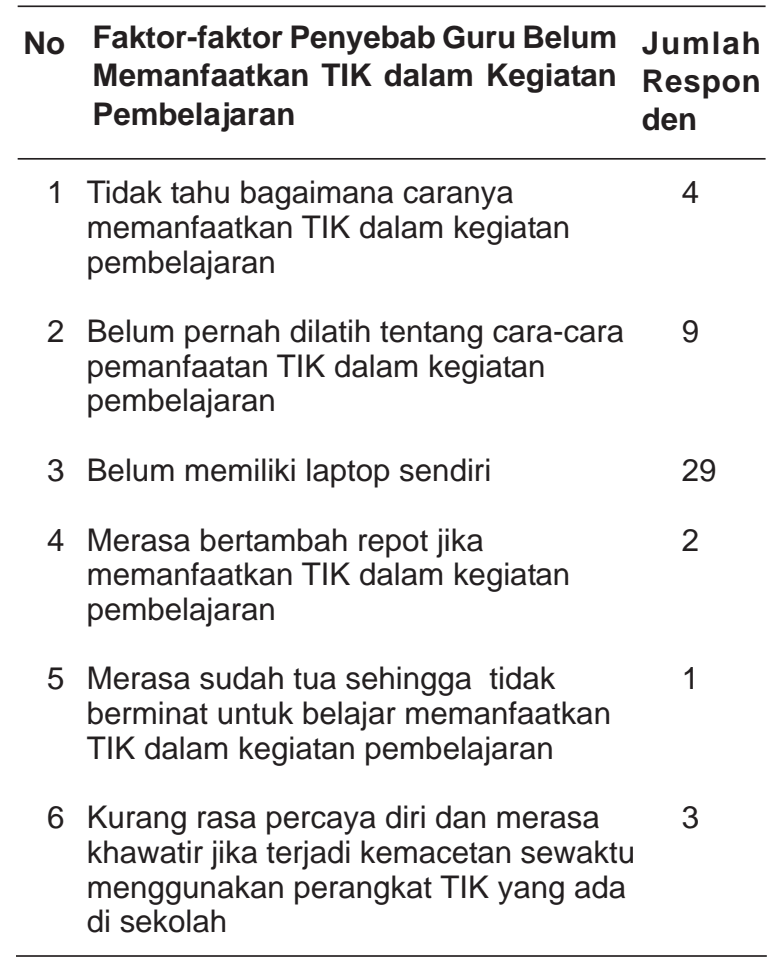

Tabel 2: Faktor-faktor Penyebab Guru Memanfaatkan TIK dalam Kegiatan Pembelajaran

Sebaliknya, pada Tabel 2 berikut ini disajikan beberapa faktor penyebab sebagian para guru telah memanfaatkan TIK dalam membelajarkan peserta didiknya.
No Faktor-faktor Penyebab Guru Jumlah Memanfaatkan TIK dalam Kegiatan Respon Pembelajaran den

1 Tergugah untuk membelajarkan 4 peserta didik melalui pemanfaatan TIK dengan cara belajar sendiri dari sesama teman guru

2 Tergugah untuk mempraktekkan pengetahuan dan keterampilan yang diperoleh selama mengikuti pelatihan tentang cara-cara pemanfaatan TIK dalam kegiatan pembelajaran

3 Tergugah untuk mengajar di dalam kelas dengan menggunakan TIK sehingga membeli laptop sendiri agar bebas untuk menggunakannya
4 Tergugah karena informasi pengalaman 8 sesama guru bahwa guru sangat terbantu dan dimudahkan dalam mengajar dengan memanfaatkan TIK

5 Termotivasi untuk lebih meningkatkan kualitas lulusan sekolah sehingga tidak ketinggalan dengan sekolah lain

6 Tidak mau disebut sebagai guru yang "gaptek" (gagap teknologi)

7 Tergugah mendengarkan pengalaman sesama guru yang telah terlebih dahulu memanfaatkan TIK dalam kegiatan pembelajaran yang memberi nilai tambah

8

Tabel 1: Faktor-faktor Penyebab Guru Belum Memanfaatkan TIK dalam Kegiatan Pembelajaran

Sementara pihak provider sebagai penyelenggara atau penyedia jasa internet berkewajiban menjamin agar program bantuan USO dapat berjalan dengan sempuna sehingga pengguna bantuan memperoleh paket internet yang tersambung langsung dengan jaringan kabel berserat optik atau Fiber Optic (FO) dari PT. Telkom. Ketersediaan jaringan berserat optik ini sendiri masih terbatas yaitu hanya di area tertentu saja. Jaringan FO ini mampu menyiapkan bandwidth besar sepenuhnya. Ciri yang lain dari program bantuan USO adalah tersedianya ruang pelayanan publik yang mendapatkan titik akses internet nirkabel (hotspot wireless) terutama bagi masyarakat di daerah perdesaan (rural).

Salah satu di antara permasalahan perangkat technoware USO yang ditemukan adalah pada saat dilakukannya pemasangan dan penetapan perangkat USO. Dalam kaitannya dengan pemberdayaan sekolah melalui program bantuan USO ini terungkap bahwa belum sepenuhnya terjalin erat koordinasi antara pihak pemerintah pusat (Kementerian Komunikasi dan Informatika dan Kementerian Pendidikan dan Kebudayaan) dengan pemerintah daerah (provinsi dan kabupaten/kota). 
Di samping koordinasi yang belum sepenuhnya terjalin baik antara pusat dengan daerah, pihak pusat juga tidak menyediakan biaya perawatan (maintenance) peralatan bantuan USO. Tanggung jawab biaya perawatan justru diserahkan langsung kepada pihak pengguna yang dalam hal ini adalah sekolah. Pihak sekolah juga tidak dilengkapi dengan manual book sebagai Petunjuk Teknis (Juknis). Manual book ini dinilai sangat penting karena di dalamnya diuraikan secara khusus tentang pembangunan jaringan area lokal (local area network, LAN). Sebagai akibatnya, ketika ada permasalahan yang dialami sekolah sebagai pihak pengguna, penyelesaiannya menjadi lebih rumit.

Komponen kedua dalam pengelolaan perangkat dan fasilitas bantuan USO adalah humanware (perangkat manusia). Artinya keterlibatan manusia dalam mengoperasikan, merawat, memperbaiki, dan bahkan melakukan inovasi terhadap sebuah teknologi sangat penting. Humanware dan brainware adalah dua bagian terpenting dalam menjalankan sebuah sistem. Tanpa SDM yang mumpuni, sebuah pekerjaan tidak akan dapat terlaksana secara baik dan benar.

Sebagaimana yang telah dikemukakan pada uraian tentang metoda yang digunakan untuk mendapatkan data dan informasi, penulis melakukan observasi terhadap operator yang ada di lapangan/sekolah, dan juga para guru yang mengajar di SMPN 2 Sakra, Kabupaten Lombok Timur.

Berdasarkan hasil observasi, ditemukan bahwa kebanyakan operator di tingkat sekolah bertugas melakukan kegiatankegiatan yang sifatnya rutin, seperti melakukan perbaikan data sekolah, data siswa, data guru, atau perbaikan sarana prasarana. Kegiatan lainnya adalah melakukan input data sekolah ke situs vervalsp.data.kemdikbud.go.id. Di samping itu, ada juga operator di sekolah yang tugasnya memproses pencairan dana BOS dan dana Kartu Indonesia Pintar (KIP).

Kemudian, melalui wawancara dengan para guru terungkap bahwa media pembelajaran berbasis internet (e-learning) memang telah mulai diterapkan di dalam proses belajar mengajar di kelas oleh sejumlah guru secara terbatas. Kegiatan pembelajaran kebanyakan dilakukan guru secara offline. Para guru juga jarang menggunakan aplikasi powerpoint (ppt.) dalam menyampaikan materi pelajaran kepada peserta didiknya.

Dalam kaitannya dengan pemanfaatan TIK atau media pembelajaran, salah seorang guru bidang studi IPS SMPN 2 Sakra mengemukakan pengalaman otodidaknya membuat media pembelajaran dengan menggunakan aplikasi tertentu. Sang guru mengatakan bahwa jika memang diperlukan, dia tidak merasa malu atau segan untuk bertanya kepada siapa saja termasuk kepada anak sekolah dalam pengembangan media pembelajaran.

Pengalaman guru lainnya dalam mempersiapkan materi pelajaran sebagai bahan presentasi di depan kelas adalah dengan cara mengunduh (download) materi pembelajaran dari Google, Youtube, dan Komunitas Guru IPA, alasannya adalah karena dirasakan lebih mudah dipelajari dan disesuaikan dengan kebutuhan. Pengalaman guru dalam membelajarkan peserta didik melalui pemanfaatan TIK diakui semakin dimudahkan, efisien, menyenangkan, praktis, menyenangkan. Dengan demikian, peserta didik menjadi terfasilitasi dalam mengerjakan tugas-tugas belajarnya sebagaimana yang disajikan pada Tabel 3 berikut ini.

Tabel 3 Manfaat yang Diperoleh Guru dalam Membelajarkan Peserta Didiknya melalui Pemanfaatan TIK

\section{No Manfaat menggunakan TIK Jumlah dalam Kegiatan Pembelajaran Respon den}

1 Tidak perlu lagi repot-repot harus 8 menulis hal-hal penting di papan tulis karena sudah tersedia dan terprogramkan sehingga tinggal memanfaatkan

2 Kegiatan pembelajaran menjadi menyenangkan dan hidup karena kontennya bervariasi, ada animasi, video, dan ada gambar 
3 Materi pelajaran dapat dibagikan kepada peserta didik sehari sebelum dibahas di kelas

4 Tugas-tugas, baik yang bersifat individu maupun kelompok dapat dibagikan kepada peserta didik beberapa hari sebelum dibahas di kelas

5 Kegiatan di kelas hanya membahas 4 materi pelajaran yang masih sulit dipahami peserta didik

6 Dengan tersedianya berbagai portal 8 tentang belajar, maka guru dan peserta didik semakin terfasilitasi dalam melaksanakan tugas-tugasnya.

Mengingat masih terbatasnya bandwith dan kadangkala kurang stabilnya koneksi jaringan, sebagian guru masih melaksanakan kegiatan pembelajaran melalui pemanfaatan TIK secara offline. Kondisi pembelajaran yang demikian ini pada dasarnya memang belum sesuai dengan hakikat tujuan pemberian bantuan USO. Tampaknya dibutuhkan waktu untuk dapat melakukan pembelajaran secara online.Tujuan pemberian bantuan USO pada hakikatnya adalah agar para guru lebih banyak melakukan pembelajaran secara online. Namun memang pada kenyataannya, pelaksanaan kegiatan pembelajaran secara online ini masih terkendala karena keterbatasan ketersediaan peralatan seperti laptop/notebook, smartphone, proyektor LCD, maupun dukungan sinyal WiFi.

Guru yang mengajar di SMPN 2 Sakra berjumlah 48 orang dengan rincian 36 orang berstatus ASN dan 12 orang guru berstatus tidak tetap (honor daerah). Kebanyakan guru yang mengajar setiap harinya masih memanfaatkan media pembelajaran whiteboard, buku paket, buku pegangan guru, Lembar Kerja Siswa (LKS), dan media sederhana yang dibuat oleh masing-masing guru. Pembelajaran dengan memanfaatkan akses WiFi hanya dilakukan di dalam laboratorium komputer. Namun demikian, sejauh ini masih terbatas pada mata pelajaran bahasa saja dan secara khusus lagi mengenai pokok bahasan speaking dan reading. Di laboratorium komputer ini juga dilakukan simulasi Ujian Nasional Berbasis Komputer (UNBK).

Melalui wawancara dengan peserta didik kelas 9,diperoleh informasi bahwa masih sebagian kecil peserta didik (sekitar 20 dari 260 peserta didik) yang aktif menggunakan perangkat dan fasilitas program bantuan USO. Dengan demikian dapatlah dikatakan bahwa hanya sekitar $7,70 \%$ peserta didik yang menikmati pembelajaran melalui pemanfaatan akses WiFi di sekolah. Kegiatan ini pun dilakukan peserta didik tanpa jadwal yang tetap. Peserta didik belajar berdasarkan inisiatif sendiri-sendiri datang ke sekolah pada sore hari untuk memanfaatkan akses WiFi yang tersedia di area sekolah mereka.

Kebanyakan peserta didik SMPN 2 Sakra yang memanfaatkan fasilitas WiFi atau hotspot di sekitar area sekolah dilakukan dengan terlebih dahulu mengakses mesin pencari Google. Diperoleh informasi bahwa kegiatan yang pada umumnya dilakukan peserta didik adalah mencari kisi-kisi soal dan berlatih mengerjakan soal-soal ujian nasional. Mereka biasanya kembali lagi datang ke sekolah pada sore hari sekitar pukul 15.30 WITA dan berada di sekolah sampai dengan pukul 17.30 WITA (atau hanya sekitar 2 jam lamanya di sekolah). Pembelajaran dengan memanfaatkan akses internet pada pagi hari sulit dilakukan disebabkan keterbatasan bandwidth yang hanya sekitar $2.0 \mathrm{Mbps}$ sajadi samping koneksi jaringan yang kadangkala kurang stabil.

Pihak sekolah sendiri telah melakukan pengecekan terhadap akses internet yang disediakan provider. Tercatat bandwidth 2.0 Mbps terjadi saat speedtest. Artinya user hanya bisa melakukan unduhan dengan kecepatan 1,79 Mbps, dan unggahan 2,06 Mbps. Dengan demikian, boleh dikatakan bahwa kecepatan akses internet ini tidak bisa mencukupi untuk melaksanakan kegiatan rutin maupun pembelajaran secara simultan. Dari kegiatan observasi yang telah dilakukan, penulis berkesimpulan bahwa persoalan yang dihadapi sekolah dalam pengelolaan bantuan USO adalah bahwa kegiatan petugas operator USO kebanyakan masih menangani 
kebutuhan administrasi (e-administrasi) sekolah, seperti kepegawaian, keuangan, absensi guru, absensi siswa, rumah tangga, dan sarana-prasarana sekolah. Sebagai akibatnya, operator USO tidak sepenuhnya fokus untuk melakukan tugas utamanya, yaitu mulai dari memelihara jaringan, melakukan edukasi, sampai dengan memecahkan berbagai persoalan yang terkait dengan pemanfaatan perangkat bantuan USO.

Selain itu, kebanyakan tenaga operator memiliki pengetahuan yang relatif masih minim, baik tentang sistem, programming maupun jaringan. Akibatnya, mereka tidak maksimal melakukan pemeliharaan peralatan komputer, server, jaringan yang terkoneksi dengan komputer client, hingga mengatur dan mengelola serta memanfaatkan bandwidth, apalagi sampai melakukan inovasi seperti misalnya membangun jaringan LAN atau Wide Local Area Network (WLAN) di sekitar sekolah.

Keterbatasan bandwidth yang diperoleh dari provider dan kadangkala kurang stabilnya koneksi jaringan berdampak pada tidak efektifnya penerapan pemanfaatan perangkat dan fasilitas bantuan USO, terutama pada jam-jam pelajaran. Saat peserta didik dan guru melakukan browsing mencari konten pembelajaran, mereka tidak didukung jaringan internet yang memadai sehingga membuat proses belajar-mengajar tidak efektif. Guru juga belum banyak meciptakan inovasi bahan belajar, misalnya dengan membuat konten pembelajaran berbasis video, audio, animasi, gambar, teks, dan foto. Padahal konten pembelajaran tersebut sangat dibutuhkan ketika guru mengalami kesulitan untuk menjelaskan topik atau pokok bahasan pembelajaran tertentu.

Guru juga tidak bisa berperan maksimal melakukan edukasi dalam penggunaan laptop, proyektor LCD, telepon genggam (smartphone) sebagai media pembelajaran yang memiliki fungsi multi akses. Sampai sejauh ini, kebanyakan tenaga pendidik (guru) masih terbatas dalam membiasakan diri menggunakan fasilitas bantuan USO. Sejatinya, dengan akses WiFi atau hotspot gratis sepanjang hari yang telah disediakan, para tenaga pendidik ini mestinya mendapat ruang di sekolah untuk berinovasi dan mengembangkan kualitas serta pengetahuannya secara berkelanjutan.

Kebanyakan guru menyimpan berbagai konten, seperti program pembelajaran, silabus, rencana pelaksanaan pembelajaran, pokokpokok bahasan, administrasi kelas, hingga kisikisi soal secara offline di laptop. Bahkan kebanyakan konten pembelajaran tersebut disimpan rapi dalam bentuk manual book sehingga rentan terjadi kerusakan atau bahkan hilang. Belum dibuat atau dikembangkannya PC server konten di sekolah sebagai tempat penyimpanan semua bahan belajar yang telah dibuat guru mata pelajaran. Kondisi yang demikian ini juga menjadi masalah yang harus segera dicari pemecahannya.

Dengan adanya PC server yang berfungsi sebagai bank data ini, kemungkinan kehilangan berbagai konten bahan belajar yang telah dibuat guru dapat diminimalisasi. Guru sendiri juga bisa menyimpan data di harddisk eksternal atau di laptopnya masingmasing. Namun dengan adanya PC server konten, kemungkinan kehilangan data dapat ditekan seminimal mungkin. Provider juga tidak pernah melakukan pendampingan secara berkala terhadap guru dan operator. Padahal pendampingan ini penting dilakukan untuk menjamin keberlangsungan pemanfaatan perangkat dan fasilitas bantuan USO di sekolah, khususnya di daerah rural, sehingga dapat menjadi lebih maksimal.

Selanjutnya tentang infoware yang identik dengan hadirnya teknologi internet. Setiap orang tidak terikat oleh negara atau batasbatas wilayah dalam mengakses dan berbagi berbagai informasi. Artinya, setiap individu dapat terhubung dan saling bertukar informasi di mana pun dan kapan pun juga. Jadi, media internet di sekolah telah menjadi model baru dalam kegiatan belajar-mengajar masa kini. Dengan layanan pendidikan melalui dunia maya dan perpustakaan online, peserta didik mampu membangun konektivitas dengan guru dalam melaksanakan sistem pendidikan terbuka dan jarak jauh.

Komunikasi antara guru dengan peserta didik kini tidak hanya melalui tatap muka saja tetapi dapat dilakukan melalui telepon, sms, email, chatting, dan bahkan peserta didik juga dapat melakukan download materi pelajaran 
yang dibutuhkan. Di samping itu, peserta didik juga dapat melakukan upload atau mengunggah konten pembelajaran. Keadaan yang demikian ini akan dapat membiasakan peserta didik untuk saling tukar konten dan mengirim file, seperti file gambar, musik, video pembelajaran, dokumen pdf. Bahkan file atau data yang dipublikasikan di internet dapat dilihat dan diunduh (downloaded) oleh publik. Ada pengalaman baru bagi peserta didik dengan diberikannya ruang untuk mencari sumber atau bahan belajar melalui dunia maya. Begitu juga bagi guru dalam pengemasan materi atau konten pembelajaran. Guru dimungkinkan untuk membuat/mengembangkan instrumen evaluasi bagi peserta didik secara beragam sesuai dengan tingkat kemampuannya.

Ranah kompetensi dalam pendayagunaan TIK bagi guru perlu ditingkatkan, mencakup kawasan kurikulum dan penilaian yang bisa dilakukan secara online, misalnya mengakses ke aplikasi atau situs tertentu seperti Kahoot untuk pengelolaan lingkungan belajar yang terbuka dan sehat. Secara nasional, tersedia situs belajar.kemdikbud.go.id yang di dalamnya terdapat slot sumber belajar, bank soal, buku sekolah elektronik, laboratorium maya, kelas maya, pengembangan keprofesian berkelanjutan, peta budaya, serta tidak menutup kemungkinan bagi guru untuk melakukan riset yang berhubungan dengan berbagai media pembelajaran.

Pihak SMPN 2 Sakra perlu membangun kemitraan dengan sekolah lain, terutama dengan SMK yang terdekat. Para guru SMK dapat melakukan pendampingan terhadap guru-guru SMPN 2 Sakra karena kompetensi guru SMK sudah cukup mumpuni, terutama dalam pendayagunaan TIK untuk kegiatan belajar-mengajar. Di SMK terdekat, sudah ada jurusan Teknologi Komunikasi Jaringan, Multimedia, dan Rekayasa Perangkat Lunak, yang menjadi unsur penting dalam rangka membangun sekolah model bermitra antarsekolah di tingkat kecamatan atau desa. Pendampingan sendiri dapat dimulai dari halhal yang sangat mendasar, seperti penggunaan berbagai aplikasi secara bertahap.
Dalam menggalakkan pemanfaatan TIK dalam kegiatan pembelajaran, ada semangat yang dikembangkan di lingkungan peserta didik SMPN 2 Sakra Kabupaten Lombok Timur, yaitu "Bawa Laptop Gotong Royong Semua Tertolong". Melalui semangat ini, tergambar bahwa jika para peserta didik bersama-sama belajar, mereka akan dapat menuntaskan tugas mereka. Sekalipun pada tahap-tahap awal kegiatan membawa laptop harus dilakukan peserta didik secara bergiliran.

Dengan adanya perangkat internet yang memadai, fungsi laptop ini bakal lebih meluas lagi karena di dalamnya para siswa bisa mendapatkan beragam konten pelajaran, baik yang diberikan oleh para guru, maupun konten pembelajaran lain yang dapat diunduh melalui berbagai situs yang ada.

Keterbatasan para peserta didik memang menjadi salah satu kendala dalam mendapatkan akses pembelajaran melalui pemanfaatan TIK ini. Namun, dengan telah masuknya akses internet ke sekolah-sekolah melalui program bantuan USO, sedikit demi sedikit cakrawala para peserta didik dan guru dapat lebih berkembang sekalipun untuk sementara waktu harus membawa laptop gotong royong agar semua dapat tertolong.

\section{SIMPULAN DAN SARAN}

SMPN 2 Sakra Kabupaten Lombok Timur terus berupaya meningkatkan kualitas sumber daya manusia di bidang pendidikan terlebih-lebih setelah SMPN 2 Sakra dan beberapa sekolah lainnya menerima bantuan perangkat dan fasilitas USO. Upaya peningkatan mutu pendidikan melalui pemanfaatan TIK dalam kegiatan pembelajaran dapat dilakukan para guru secara bertahap dan berkelanjutan sehingga terjadi optimalisasi pemanfaatan TIK yang tersedia.

Untuk sekolah-sekolah lainnya yang berada di daerah 3T, Pustekkom Kemendikbud perlu: (1) membuat model diklat online tentang peningkatan pengelolaan perangkat bantuan USO yang antara lain misalnya mencakup pemanfaatan perangkat technoware; dan (2) menyelenggarakan diklat 
dan bimbingan teknis (bimtek) kepada tenaga pendidik dan kependidikan serta teknisi yang berperan sebagai ujung tombak di lapangan. Konten diklat atau bimtek dapat saja mencakup penggunaan aplikasi e-adminstrasi guru dan e-learning atau pembuatan media bahan belajar dengan aplikasi,mobile learning, m-edukasi, microsoft word, microsoft excel, powerpoint, animasi, desain konten pembelajaran, dan video pembelajaran.

Konten diklat dapat juga mencakup pengembangan media pembelajaran sesuai dengan kebutuhan peserta didik disabilitas (penyandang cacat) dan untuk peserta didik normal.

Memperhatikan berbagai potensi yang ada di masyarakat termasuk di daerah 3T, yaitu berkembangnya berbagai komunitas, seperti Komunitas Desa Berdering, Internet Desa, Kampung Media, Radio Online, maupun TV Lokal, pemerintah pusat dan daerah perlu mengembangkan kemitraan kerja dengan berbagai komunitas ini untuk percepatan pembangunan daerah 3T, khususnya di bidang pendidikan.

Mempertimbangkan berbagai kondisi yang ada pada umumnya di daerah 3T, seperti: keterbatasan dan keterjangkauan akses internet dan topografi desa yang berbeda-beda, baik iklim maupun alamnya, disarankan untuk memperbanyak server konten pembelajaran model offline yang dapat diakses sekalipun tidak ada koneksi internet atau koneksi internetnya mengalami gangguan.

\section{PUSTAKA ACUAN}

\section{Buku}

Aziz, M. dkk. (2016). Inspirasi Pendidikan di Perbatasan: Menghadirkan Teknologi Informasi, Berjuang Melampaui Keterbatasan. Ciputat-Tangerang Selatan: Pusat Teknologi Informasi dan Komunikasi Pendidikan dan Kebudayaan-Kementerian Pendidikan dan Kebudayaan.

Santoso, A. (2016). Inspirasi Pendidikan di Perbatasan: Menghadirkan Teknologi Informasi, Berjuang Melampaui Keterbatasan. Ciputat-Tangerang Selatan: Pusat Teknologi
Informasi dan Komunikasi Pendidikan dan Kebudayaan-Kementerian Pendidikan dan Kebudayaan.

Suharwoto, G. (2018). An Introduction in Educator Inspiration from the Frontiers. Jakarta: ICT Center-Ministry of Education and Culture.

UNESCO Asia-Pacific Regional Bureau for Education APEID/ICT Education. (2013). ICT in Education, Policy, Infrastructure, and ODA Status in Selected ASEAN Countries. Bangkok: UNESCO Asia-Pacific Regional 429 Bureau for Education APEID/ICT Education. http:// www.unescobkk.org/ fileadmin/ user_upload/ ict/ebooks/ICT_in_Education_ Policies_Infrastructure_and_ODA.pdf (Diakses tanggal 09 September 2018).

\section{Jurna/Prosiding/Disertasi/Thesis/Skripsi}

Anwar, M. T.(2016). Evaluasi Penggunaan TIK dalam Pembelajaran di Sekolah Menengah Atas (SMA) di Kota Salatiga(Skripsi). Salatiga:

Ariani, D.(2009). Pembelajaran Berbasis TIK terhadap Orang Dewasa. Jurnal TEKNODIK. Vol. 13, No. 1.

Hariadi.(2016). Pemanfaatan Teknologi Informasi dan Komunikasi terhadap Hasil Belajar pada Mata Pelajaran Ekonomi di SMA (Skripsi). Pontianak: Universitas Tanjungpura.

Husain, C. (2014). Pemanfaatan Teknologi Informasi dan Komunikasi dalam Pembelajaran di SMA Muhammadiyah Tarakan. Jurnal Kebijakan dan Pengembangan Pendidikan Volume 2, Nomor 2.

Rivalina, R. (2015). Pemanfaatan TIK dalamPembelajaran di SDN Cipayung 1, Ciputat, Tangerang Selatan, Banten. Jurnal Teknodik Vol. 19 No. 2.

Rivalina, R. dan Siahaan, S. (2013). Tanggapan Awal terhadap Pemanfaatan TIK dalam Kegiatan Pembelajaran di Kabupaten Belu.Jurnal TEKNODIK Vol. 17 No. 4.

Siahaan, S. (2013). Menuju Ke Arah Pendidikan Berkualitas di Daerah Tertinggal dan Perbatasan Melalui Pemanfaatan TIK. Jurnal TEKNODIK Vol. 17 Nomor 1.

Siahaan, S. (2015). Pemanfaatan Teknologi Informasi dan Komunikasi dalam Pembelajaran: Peluang, Tantangan, dan Harapan. Jurnal TEKNODIK Vol. 19 Nomor 3. 
Warsihna, J. (2013). Pemanfaatan Teknologi Informasi dan Komunikasi (TIK) untuk Pendidikan Daerah Terpencil, Tertinggal, dan Terdepan (3T).Jurnal TEKNODIK Vol. 17 Nomor 2.

\section{Lain-lain}

Cahyani, R. dan Krisnadi, I.Tanpa tahun.Studi Komparasi Penerapan Universal Service Obligation Bidang Telekomunikasi.http:// www. academia.edu/37960956/ Studi_Komparasi_Penerapan_Universal_ Service_Obligation_Bidang_Telekomunikasi (Diakses: 14 Jan 2019).

Humas BP3TI KOMINFO. (2016). LatarBelakang Program USO Telekomunikasi dan Informatika.Jakarta: Kementerian Komunikasi danInformatika.https://humasbp3ti kominfo.wordpress.com/2016/07/16/latarbelakang-program-uso-telekomunikasi-daninformatika/ (Diakses 13 Januari 2019).

Kementerian Komunikasi dan Informatika. (2015). Peraturan Menteri Komunikasi dan Informatika Nomor 25 Tahun 2015 Universitas Kristen Satya Wacana.

Pelaksanaan Kewajiban Pelayanan Universal Telekomunikasi dan Informatika.Sumber: (https://jdih. kominfo.go.id/produk_hukum/view/ id/357/t/peraturan+menteri+komunikasi+ dan+informatika+nomor+25+tahun+ 2015+tanggal+1+juli+2015)(Diakses 23 Januari 2019).

Marwanto, E. Informasi Program USO (Universal Service Obligation).Sumber:https:// www.ekomarwanto.com/2012/07/informasiprogram-uso-universal-service.html (Diakses tanggal 14 Januari 2019).
Pustekkom, Depdiknas. (2011). Laporan Rapat Koordinasi Pemanfaatan Teknologi Informasi dan Komunikasi di Bali. Dokumen Tidak Dipublikasikan. Jakarta: Pustekkom Depdiknas

Pustekkom. (2012). Laporan Kegiatan Pendampingan Layanan Pendidikan di Daerah Tertinggal, Terpencil, Terdepan dan Terdekat (4T) Marore, Kabupaten Sangihe. Dokumen Tidak Dipubalikasikan. Ciputat-Tangerang Selatan: Pusat Teknologi Informasi dan Komunikasi Pendidikan-Kementerian Pendidikan dan Kebudayaan.

Pustekkom. (2012). Laporan Hasil Monitoring dan Evaluasi Pusat Sumber Belajar untuk Daerah Terpencil, Tertinggal, dan Terdepan. DokumenTidak Dipublikasikan. CiputatTangerang Selatan: Pusat Teknologi Informasi dan Komunikasi Pendidikan dan KebudayaanKementerian Pendidikan dan Kebudayaan.

SMP Negeri 2 Sakra. (2018). Data tentang Bantuan Perangkat USO. Dokumen Dokumen Tidak Dipublikasikan. Sakra-Lombok Timur: SMPN2.

https://id.wikipedia.org/wiki/ Kewajiban_ Pelayanan_Universal (Diakses tanggal 09 September 2018).

https://kominfo.go.id/content/detail/ 8444/programuso-mampu-jembatani-akses-internet-605sekolah/0/sorotan_ media)(Diakses tgl 25 Januari 2019).

https://humasbp3tikominfo.Wordpress.com/2016/ 07/16/latar-belakang-program-usotelekomunikasi-dan-informatika/ (Diakses tgl 23/01/19). 